\title{
Hydrogen as a future fuel, challenges and opportunities: An overview of modelling approaches
}

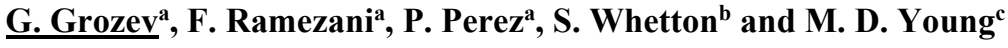 \\ ${ }^{a}$ SMART Infrastructure Facility, University of Wollongong, ${ }^{b}$ SA Centre for Economic Studies, \\ University of Adelaide, ${ }^{c}$ Centre for Global Food and Resources, University of Adelaide \\ Email: faribark@uow.edu.au
}

\begin{abstract}
When consumed, hydrogen produces water and energy but no greenhouse gas emissions. This great advantage has attracted many governments and industries around the world that aim to decrease their emissions and the number of policies and projects supporting clean hydrogen industry is increasing quickly. Yet, the implications of hydrogen industry at large scale is uncertain. In this paper, we provide an inventory of the techno-economic models that have been developed and /or can be adapted to investigate the opportunities and challenges of hydrogen as an alternative energy resource for Australia. We review 8 well-known technoeconomic models and categorised them based on their characteristics including type, regional and time scale and the inclusion of gas and electricity systems. In the next step of this study, we will look into the key Characteristics related to future fuels such as inclusion (or the capacity of inclusion) of carbon accounting, and energy storage solution.
\end{abstract}

Keywords: Techno-economic modelling, energy resource, hydrogen, energy network 


\section{INTRODUCTION}

Over the last decade and with the increasing international concerns of reducing greenhouse gas (GHG) emissions, the need to decarbonise energy systems and finding alternative low-carbon fuels have become significant. Hydrogen is an alternative that can be used across all sectors including transportation, commercial, industrial and residential to produce heat, electricity and only water as by-product. It can also support energy security. This make hydrogen to be considered as a future fuel by many regions and countries across the world and many researchers attempt to investigate the environmental and economic impacts of using hydrogen at national and regional level.

There are several technologies to produce hydrogen including two mature pathways of thermochemical and electrochemical. In thermochemical approach, a fossil fuel feedstock (such as natural gas and coal) is used to produce hydrogen. In order to obtain clean hydrogen (so called blue hydrogen in this method), the process is paired with carbon capture and storage (CCS). The mature technology of this approach is Steam Methane Reforming (SMR). In the second approach, electricity is used to split water into hydrogen and oxygen. If renewable electricity is used, clean hydrogen (so called green hydrogen in this approach) can be obtained. Polymer Electrolyte Membrane (PEM) and Alkaline Electrolysis (AE) are the mature technologies of this method.

Like Liquefied Natural Gas (LNG), hydrogen can be transported as gas by pipelines, or as liquid by ships. Additionally, hydrogen can be used to store and/or transport renewable energies from regions with considerable solar and wind resources to where the demand is high.

Despite these great advantages, hydrogen hasn't been produced and used at large scale yet because it is costlier than other energies. Currently, the levelised cost of hydrogen ( $\mathrm{LCOH}$ ) is $\$ 6.08-7.43 / \mathrm{kg}$ for PEM technology and $\$ 2.27-2.77 / \mathrm{kg}$ for SMR technology (Bruce, et al. 2018). However, investing can improve technologies and develop hydrogen industry around the world. Additionally, governments should ensure that existing regulations are not a barrier to investment. With hydrogen production technology improvements, scaling up, and decrease in renewable energy prices, hydrogen will be a competitive energy in future. For instance, the International Energy Agency (2019) forecasts that the cost of producing hydrogen from renewable electricity could fall by $30 \%$ by 2030 due to the renewables costs reduction and the scaling up of hydrogen production. Likewise, Bruce, et al. (2018) estimates that by 2030 , the production cost of producing hydrogen could decease to $\$ 2.29$ $2.79 / \mathrm{kg}$ and $\$ 1.88-2.30 / \mathrm{kg}$ via PEM and SMR technologies, respectively.

Although hydrogen is considered as a future fuel by governments and industries around the world, the potential implications of hydrogen industry is currently uncertain. This paper aims to provide an inventory of existing simulation models used to assess the constraints and opportunities of energy transitions in Australia and beyond. In particular, we review well-known techno-economic models that have been used in the context of energy transition analyses, or have the potential to do so.

This paper continues as follows. Section 2 provides a summary of the techno-economics models. The conclusion will be presented in Section 3. Finally, the acknowledgment will be presented in Section 4.

\section{TECHNO-ECONOMIC MODELLING REVIEW}

Over the last two decades, energy systems and markets have been in rapid transition in many countries. They have been challenged by many developments, including:

- liberalisation and restructuring of electricity markets;

- introduction of environmental policies for energy decarbonisation;

- significant growth of large scale renewable generation (wind and solar farms), and significant reductions in the capital cost of such generation;

- emergence of distributed local energy generation (such as solar PV, wind energy, batteries and "smart" energy control systems).

Regulations and rules used to manage these energy systems have also been in a state of ongoing flux. As a result, whole-of-system dynamic economic models have been found unable to address the new complexities of the decentralised and liberalised electricity markets. As a result, hybrid techno-economic models of energy 
systems aim to provide a more accurate description of the interactions between economic decisions and technological choices. In a nutshell, these models represent energy demand, supply, distribution, storage and trading, based on various technological pathways and sets of regulations (Foley et al., 2010). Although most of these models initially focused on electricity systems and markets, they have progressively incorporated gas systems in order to reflect their growing influence. In the context of competitive electricity markets, such as Australia's National Electricity Market (NEM), regulators increasingly rely on these models to represent the system and predict its short-term to medium-term behaviour.

Overall, energy systems models can be clustered into three main groups (Sarica et al., 2012):

- Optimisation models

- Equilibrium models

- Simulation models

Optimisation models focus on least-cost expansion of the whole system, or profit maximisation of one firm competing in the market. Equilibrium models rely on competition considerations in relation to market participants when presenting the overall market dynamics. Simulation models are usually an alternative to the optimisation and equilibrium models when the problem to be represented and solved is too complex to be dealt with an optimisation or equilibrium framework.

A comprehensive review of different computer modelling tools that can be used to analyse the integration of renewable energy is presented by Connolly et al. (2010). 37 tools (from a single building system to a national system) are included in the final analysis. It includes two of the selected tools in this review - EMCAS and TIMES.

Table 1. Techno-economic models

\begin{tabular}{|l|l|l|}
\hline Model & Organisation (link) & Country \\
\hline EMCAS & $\begin{array}{l}\text { Argonne National Laboratory (ANL), } \\
\text { https://ceeesa.es.anl.gov/projects/emcas.html }\end{array}$ & USA \\
\hline ESME & http://www.eti.co.uk & UK \\
\hline EWG-LUT & $\begin{array}{l}\text { EnergyWatchGroup, Berlin and } \\
\text { LUT University, Lappeenranta }\end{array}$ & $\begin{array}{l}\text { Germany and } \\
\text { Finland }\end{array}$ \\
\hline Genersys & CSIRO and GW Simulation & Australia \\
\hline Jacobs & $\begin{array}{l}\text { Jacobs (2017): Report to the Independent Review into the Future Security } \\
\text { of the National Electricity Market }\end{array}$ & Australia \\
\hline PLEXOS & Energy Exemplar Pty Ltd, Adelaide, SA, https://energyexemplar.com/ & Australia \\
\hline REMod-D & $\begin{array}{l}\text { Fraunhofer Institute for Solar Energy System (ISE), Freiburg, } \\
\text { https://www.ise.fraunhofer.de/en/press-media/press-releases/2015/what- } \\
\text { will-the-energy-transformation-cost.html }\end{array}$ & Germany \\
\hline TIMES & $\begin{array}{l}\text { The Energy Technology Systems Analysis Program (ETSAP), https://iea- } \\
\text { etsap.org/ }\end{array}$ & $\begin{array}{l}\text { International } \\
\text { Energy Agency } \\
\text { (IEA), France }\end{array}$ \\
\hline
\end{tabular}

Connolly et al. (2010) consider seven different tool types when reviewing these models:

- Simulation tool. A simulation tool simulates the operation of the system components. Typically, simulation tools operate at a given time interval - hour, day, year, etc.

- Scenario tool. A scenario tool is usually used to describe the evolution of an energy supply system over several years. A typical time horizon is 20-50 years.

- Equilibrium tool. An equilibrium tool aims to explain the behaviour of supply, demand and prices in the whole economy or in some sectors of the economy (general or partial equilibrium). Based on 
economic theory, it is assumed that an equilibrium could be achieved between producers and consumers in terms of the prices of the products and supply and demand.

- Top-down tool. A top-down tool is a macroeconomic tool that uses generic data to determine the evolution of the energy prices and energy demand services. Typically, top-down models are also equilibrium models.

- Bottom-up tool. A bottom-up tool builds the energy system to be modelled and analysed by its components - for example representing all major energy generating units and plants in a region of interest.

- Optimisation tool. An optimisation tool optimises the operation of a given energy system. The system model is represented as an optimisation problem with an objective function (e.g., minimising total cost) and a set of constraints. The optimisation problem is solved by software engines based on linear or non-linear programming algorithms. The power of linear programming is that it can find an optimal solution to a problem with many thousands or even hundreds of thousands of decision variables. Many optimisation tools also include simulation modules to represent some components and operations of the modelled system.

- Investment tool. Some tools optimise or simulate capacity expansion or investment in new generation plants, new transmission lines, etc. Typically, these tools are also scenario-based tools.

The type of each techno-economic model reviewed in this paper is represented in Table 2. All these models are bottom-up models, so no column for top-down models is included in this Table.

Table 2. Type of each techno-economic model reviewed

\begin{tabular}{|l|l|l|l|l|l|l|}
\hline Model & Simulation & Scenario & Equilibrium & Bottom-up & Optimisation & Investment \\
\hline EMCAS & Yes & Yes & - & Yes & - & Yes \\
\hline ESME & -1 & Yes & - & Yes & Yes & Yes \\
\hline EWG-LUT & - & Yes & - & Yes & Yes & Yes \\
\hline Genersys & Yes & Yes & - & Yes & -2 & Yes \\
\hline Jacobs & Yes & Yes & & Yes & - & Yes \\
\hline PLEXOS & -3 & Yes & - & Yes & Yes & Yes \\
\hline REMod-D & Yes & Yes & - & Yes & Yes & Yes \\
\hline TIMES & - & Yes & Yes & Yes & Yes & Yes \\
\hline
\end{tabular}

\footnotetext{
${ }^{1} \mathrm{ESME}$ has a module for Monte Carlo simulations in order to consider uncertainty of future energy prices and future cost of energy technologies.

${ }^{2}$ Genersys uses an optimisation dispatch heuristic.

${ }^{3}$ PLEXOS has a Monte Carlo simulation of forced outages and optimised maintenance.
} 
Table 3. Type of analysis conducted by each tool

\begin{tabular}{|c|c|c|c|c|c|c|}
\hline Model & $\begin{array}{l}\text { Geographical } \\
\text { area }\end{array}$ & $\begin{array}{l}\text { Scenario } \\
\text { timeframe }\end{array}$ & Time-step & Electricity & Gas & Renewables \\
\hline EMCAS & $\begin{array}{l}\text { Regional, } \\
\text { State, } \\
\text { National }\end{array}$ & $\begin{array}{l}\text { Several } \\
\text { decades }\end{array}$ & Hourly & Yes & - & Yes \\
\hline ESME & $\begin{array}{l}\text { National (UK), } \\
\text { Regional }\end{array}$ & 2050 & $\begin{array}{l}\text { 5-year; } \\
2 \text { seasonal \& } 5 \\
\text { diurnal time } \\
\text { slices }\end{array}$ & Yes & Yes & Yes \\
\hline EWG-LUT & $\begin{array}{l}\text { Europe, } \\
20 \quad \text { European } \\
\text { regions }\end{array}$ & 2050 & Hourly & Yes & Yes & Yes \\
\hline Genersys & $\begin{array}{l}\text { Regional, } \\
\text { State, } \\
\text { National }\end{array}$ & $\begin{array}{l}\text { Several } \\
\text { decades }\end{array}$ & Hourly & Yes & Yes & Yes \\
\hline Jacobs & $\begin{array}{l}\text { Regional, } \\
\text { State, } \\
\text { National } \\
\end{array}$ & 2050 & Hourly & Yes & Yes & Yes \\
\hline PLEXOS & $\begin{array}{l}\text { Region, } \\
\text { Several states, } \\
\text { Big } \\
\text { interconnection }\end{array}$ & $\begin{array}{l}\text { Several } \\
\text { decades for } \\
\text { capacity } \\
\text { expansion }\end{array}$ & $\begin{array}{l}5 \mathrm{~min}, \\
60 \mathrm{~min} \text { (default) }\end{array}$ & Yes & Yes & Yes \\
\hline REMod-D & $\begin{array}{l}\text { Germany, } \\
2 \text { regions }\end{array}$ & 2050 & Hourly & Yes & Yes & Yes \\
\hline TIMES & $\begin{array}{l}\text { Regional, } \\
\text { State, } \\
\text { National }\end{array}$ & $\begin{array}{l}\text { From one } \\
\text { year to many } \\
\text { decades }\end{array}$ & $\begin{array}{l}\text { Hourly, daily, } \\
\text { monthly using } \\
\text { user-defined } \\
\text { time slices }\end{array}$ & Yes & Yes & Yes \\
\hline
\end{tabular}

Close collaboration between model designers, industry stakeholders and policy makers is critical for the development of relevant and useful modelling scenarios (Chiodi et al., 2015). And importantly, the value of any given modelling output, regardless of its accuracy, rests on the capacity of the modellers and key stakeholders to engage with a broader audience, to establish trusted communication channels and to adapt the messages in the most compelling way.

\section{CONCLUSION}

This paper is a part of a project supported by Future Fuels CRC to investigate the implication of decarbonising gas networks by shifting from natural gas to hydrogen. Such implications are typically explored through techno-economic models. This review aims to provide an inventory of existing simulation models used to assess the constraints and opportunities of energy transitions in Australia and beyond. We have reviewed 8 well-known models including EMCAS, ESME, EWG-LUT, Genersys, Jacobs, PLEXOS, REMod-D and TIMES. We have categorised these models based on their type (i.e. optimisation, equilibrium, simulation), regional and time scale, and the inclusion of both electricity and gas energy systems. In the next step, we will review the capacity to impose specified restrictions on the greenhouse gas intensity of energy (as reflected in the basket of energy technologies: coal, natural gas, solar, wind, hydro, future fuels, nuclear and other renewables); to model various energy storage solutions (battery, pumped hydro, heat conversion, compressed air storage, or hydrogen); to model the impact of supply and demand on the cost of transmission and distribution networks, as well as the impact on energy prices; and to include carbon accounting and estimation of emissions produced under each scenario.

\section{ACKNOWLEDGMENTS}

This work was funded by the Future Fuels CRC, supported through the Australian Government's Cooperative Research Centres Program. 


\section{REFERENCES}

Bruce, S., Temminghoff, M., Hayward, J., Schmidt, E., Munnings, C., Palfreyman, D., Hartley, P. (2018). National Hydrogen Roadmap. CSIRO, Australia.

Chiodi A et al. (2015). Energy Policies Influenced by Energy Systems Modelling-Case Studies in UK, Ireland, Portugal and G8. In G. Giannakidis et al. (eds.), Informing Energy and Climate Policies Using Energy Systems Models, Lecture Notes in Energy 30. DOI 10.1007/978-3-319-16540-0_2

Connolly D, Lund H, Mathiesen BV, Leahy M (2010). A review of computer tools for analysing the integration of renewable energy into various energy systems. Applied Energy 87, 1059-1082. doi:10.1016/j.apenergy.2009.09.026

$\begin{array}{llllll}\text { Energy } & \text { Exemplar } & \text { (2019). } & \text { PLEXOS }{ }^{\circledR} & \text { Energy } & \text { Simulation }\end{array}$ https://energyexemplar.com/products/plexos-simulation-software/

Energy Systems Catapult (2017). ESME Data Reference Book. 80 pp report prepared for ETI. Available online: https://www.eti.co.uk/library/esme-data-references-book

Fishbone, LG. and Abilock, H. (1981). MARKAL, a linear programming model for energy systems analysis: technical description of the BNL version. Int J Energy Res 5:353-375.

Foley, AM. Gallachóir, BPÓ. Hur, J. Baldick, R. McKeogh, EJ. (2010). A strategic review of electricity systems models. Energy 35, 4522-4530. doi:10.1016/j.energy.2010.03.057

Genersys User Guide, 289 pp, (2018).

Grohnheit, PE. (1991). Economic interpretation of the EFOM model. Energy Economics, 13(2), 143-152. https://doi.org/10.1016/0140-9883(91)90047-4

Grozev, G., James, M., Batten, D., Page, J. (2014). How to Characterise and Parameterise Agents in Electricity Market Simulation Models: The Case of Genersys. pp 171-188. In Smajgl A and Barreteau O (Editors), Empirical Agent-Based Modelling - Challenges and Solutions: Volume 1, The Characterisation and Parameterisation of Empirical Agent-Based Models, Springer, New York, 2014. DOI: 10.1007/978-14614-6134-0_9

Heaton, C. (2014). Modelling low-carbon energy system designs with the ETI ESME model. Energy Technology Institute. Available online: https://www.eti.co.uk/library/modelling-low-carbon-energysystem-designs-with-the-eti-esme-model

Henning, H-M., Palzer, A. (2016). What will the energy transformation cost? Pathways for transforming the German energy system by 2050. Fraunhofer ISE, 87 pp. (Available online: https://www.ise.fraunhofer.de/en/publications/studies/what-will-the-energy-transformation-cost.html, accessed on 5/4/2019)

International Energy Agency, (2019). The Future of Hydrogen. Report prepared by the IEA for the G20, Japan.

Jacobs Group (Australia) Pty Limited (2017). Report to the Independent Review into the Future Security of the National Electricity Market Emissions mitigation policies and security of electricity supply, Project no RO046300

Loulou, R. (2007). ETSAP-TIAM: the TIMES integrated assessment model. part II: mathematical formulation. Comput. \& Manag. Science 5 (1-2), 41-66. DOI 10.1007/s10287-007-0045-0

Loulou, R. and Labriet, M. (2008). ETSAP-TIAM: the TIMES integrated assessment model Part I: Model structure. Comput. \& Manag. Science 5 (1-2), 7-40. DOI 10.1007/s10287-007-0046-z

Sarıca, K., Kumbaroğlu, G., Or I. (2012). Modeling and analysis of a decentralized electricity market: An integrated simulation/optimization approach. Energy 44, 830-852. doi:10.1016/j.energy.2012.05.009 